\title{
Trust Types and Mediating Effect of Consumer Trust in m- payment Adoption: An empirical Examination of Vietnamese Consumers
}

\author{
Tuan Anh Nguyen \\ RMIT University, Australia \\ s3641842@student.rmit.edu.au
}

Hiep-Cong Pham

RMIT University Vietnam, Viet Nam

Martin Dick

RMIT University, Australia

\section{Joan Richardson}

RMIT University, Australia

\section{Abstract}

This study employs a quantitative method to investigate different types of trust in m-payment adoption. It aims to overcome the limitation of previous studies which are a lack of differentiating trust types and investigating any mediating effect to m-payment adoption. Data of the study was collected in Vietnam, one of fastest growing m-payment usage markets globally in 2019. The research found significant and positive impacts of $\mathrm{m}$-payment provider trust, institution-based trust, and seller trust on the overall consumer trust, which then fully mediates the relationships of three trust types and m-payment adoption. The study also revealed that technology trust is embedded in m-payment provider trust, suggesting that the $\mathrm{m}$-payment provider is considered fully responsible for ensuring technology protection from the perspective of the m-payment consumers. The results enable researchers to better understand trust characteristics in m-payment adoption as well as technology adoption in general. In addition, the findings are beneficial to practitioners such as policy makers, consultants, and m-payment service providers to improve different elements of consumer trust, leading to higher m-payment adoption.

Keywords: mobile payment adoption, consumer trust, trust types, technology adoption

\section{Introduction}

Mobile payment (m-payment) refers to financial transactions made via mobile devices, such as, tablets and mobile phones (Stringfellow, 2018). In other words, m-payment consumers can use mobile devices to pay for goods or services that they purchase, instead of using cash, debit cards, credit cards or any other type of bank card. M-payment is considered to be a subset of mobile commerce (m-commerce), as well as, electronic commerce (e-commerce) which processes the payment transaction for customers when purchasing goods or services (Kreyer, Pousttchi, \& Turowski, 2002; MobiForge, 2014).

There are two types of m-payment namely remote and proximity m-payment. The former refers to m-payment transactions which can be conducted from a distance and consumers do not need to directly interact with sellers or the merchants' point of sale systems (POS). Common examples of remote m-payment are carrier billing, short message service (SMS) 
payments or using mobile phones to pay online via applications, such as, Paypal (Emily, 2018). In contrast, proximity m-payment methods using Near Field Communications (NFC), allow customers to directly pay for their purchase using their mobile phones with m-payment applications, such as, Apple Pay, Samsung Pay or Google Pay, or scanning a seller's QR (Emily, 2018). M-payment is considered as a state-of-the-art payment method in the modern world as it builds upon the Internet and mobile devices (Kolaki, 2017). Global use of mpayment is forecasted to increase $28 \%$ by 2022 and surpass cash and credit cards in the longer term, which will contribute to the future of a cashless world (MerchantSavvy, 2019). In the current situation where COVID-19 has spread across the globe, the usage of m-payment is growing at an even faster rate as it is considered as a safer way to pay rather than traditional payment transactions that require cash (ResearchAndMarkets, 2020).In the area of m-payment adoption, trust is defined as customers/consumers' beliefs and willingness to rely on $\mathrm{m}$ payment for transactions (adapted from Alhulail, 2018; McKnight, Choudhury, \& Kacmar, 2002; Xin, Techatassanasoontorn, \& Tan, 2015). Trust plays an important role in m-payment adoption in both research and practice. In research, many studies empirically found a significant effect of trust on m-payment adoption by individual consumers (Andreev, Pliskin, \& Rafaeli, 2012; Liu, 2012; Patil, Rana, Dwivedi, \& Abu-Hamour, 2018).(Andreev et al. 2012; Liu 2012; Patil et al. 2018). In practice, a lack of trust is reported as one of the main barriers to m-payment adoption, resulting in low rates of technology service use (Asatryan, 2017; Shuhaiber, 2016). It can be summarised that trust is one of the key drivers for intention to adopt, as well as, acceptance of m-payment (Alalwan, Dwivedi, \& Rana, 2017).

However, most previous studies in m-payment adoption assess trust as a single construct and examine the impact of trust on other factors, such as, perceived usefulness and intention to adopt m-payment without differentiating types of trust constituting to the more general term. Researchers have pointed out that trust is a complex phenomenon, thus it should be modelled as a multidimensional or multifaceted construct (Hillman \& Neustaedter, 2017; Jimenez, SanMartin, \& Azuela, 2016). In particular, exploring different types of trust in m-commerce or mpayment enables researchers to better understand trust as a phenomenon which ultimately allows predictions of consumer adoption (Meng, Min, \& Li, 2008; Min, Meng, \& Zhong, 2008; Nguyen, Dick, \& Pham, 2020). Consequently, the identification of different types of trust in mpayment adoption needs to be addressed further (Nguyen et al., 2020).(Nguyen et al. 2020).

This study argues that overall consumer trust plays a mediating role between various trust types and m-payment adoption. Such trust types are initiated from multiple aspects of $\mathrm{m}$ payment context. In particular, it aims to ascertain the impact of four types of trust including m-payment provider trust, technology trust, institution-based trust, and seller trust, which are well-defined from related literature, on overall consumer trust which in turn influences mpayment usage. The findings of this study not only contribute to the literature of trust in technology, as well as, in m-payment adoption, but also helps practitioners to improve customer trust, thereby increasing the adoption of m-payment services.

The data collection was undertaken in Vietnam which had the fastest global m-payment adoption growth rate, from $37 \%$ in 2018 to $61 \%$ in 2019 (PwC, 2019). Consumers choice to use m-payments in Vietnam is voluntary. By 2018, the number of smartphone users in Vietnam was about 32.43 million which accounted for around $33 \%$ of the population, and it was forecasted to increase to $40 \%$ by 2021 (Statista, 2018). Vietnam's financial technological market reached US $\$ 4.4$ billion in 2017 and was forecasted to increase to US $\$ 7.8$ billion by 2020 
(Fintechnews, 2018a). The booming e-commerce market and support from the Vietnamese government were expected to lead to a boom in digital payments, especially m-payments in Vietnam (Fintechnews, 2018b).

This paper is organised as follows. The next section presents the literature review, description of the limitations of existing studies, and research questions. Then the research model and hypotheses are presented. The fourth and fifth sections in turn present the research methodology and data analysis. Finally, the implications, limitations, and future research are discussed.

\section{Literature Review}

\subsection{Previous Studies about Trust in E-commerce, M-commerce, and M- payment Adoption}

The term trust is used frequently in daily life, however it is still difficult to provide a comprehensive and full definition of trust across different disciplines because it is a complex phenomenon including distinctive aspects (McKnight \& Chervany, 2001a). Trust is recognised as a multi-disciplinary term due to existing research exploring and examining trust in a wide variety of contexts and incorporating perspectives of different disciplines like psychology, economics, commerce, management and behavioural science (McKnight \& Chervany, 2001b).

In the areas of e-commerce and m-commerce, trust has received attention in a number of studies (e.g. Bilgihan, 2016; Hallikainen \& Laukkanen, 2018; Hillman \& Neustaedter, 2017; Lin, Wang, Wang, \& Lu, 2014; Lu, Fan, \& Zhou, 2016; Malaquias \& Hwang, 2016; Piao, Wang, \& Yang, 2012; Rouibah, Lowry, \& Hwang, 2016). McKnight and Chervany (2001b) applied their interdisciplinary model of high-level trust concepts to e-commerce to propose a model of ecommerce customer relationship trust to improve the service provided to customers and relationships built with a view to a positive impact on the business performance.

In e-commerce, trustors are e-commerce consumers, trustees are e-vendors. Disposition to trust reflects the extent to which an e-commerce consumer "has a general propensity/tendency to depend on most people across most situations" (McKnight \& Chervany, 2001b, p. 43). Institution-based trust is the belief that the necessary conditions, such as, regulations, laws, security, and protocols of the Internet, are present in order to increase the likelihood of participating in e-commerce (McKnight et al., 2002). Interpersonal trust refers to a person trusting another one across diverse contexts (McKnight \& Chervany, 2001b). The following four constructs including disposition to trust, institution-based trust, trusting beliefs and trusting intentions are subdivided into lower-level constructs to be measured via relevant scales:

- Disposition to trust includes faith in humanity and a trusting stance,

- Institution-based trust includes structural assurance and situational normality,

- Trusting beliefs encompass competence, benevolence, integrity, and predictability belief, and

- Trusting intentions cover willingness to depend and subjective probability of depending. 
McKnight et al. (2002) integrated their model of e-commerce customer relationship trust with the Theory of Reasoned Action (TRA) (Fishbein \& Ajzen, 1975) to propose and test the web trust model in e-commerce (figure 1).

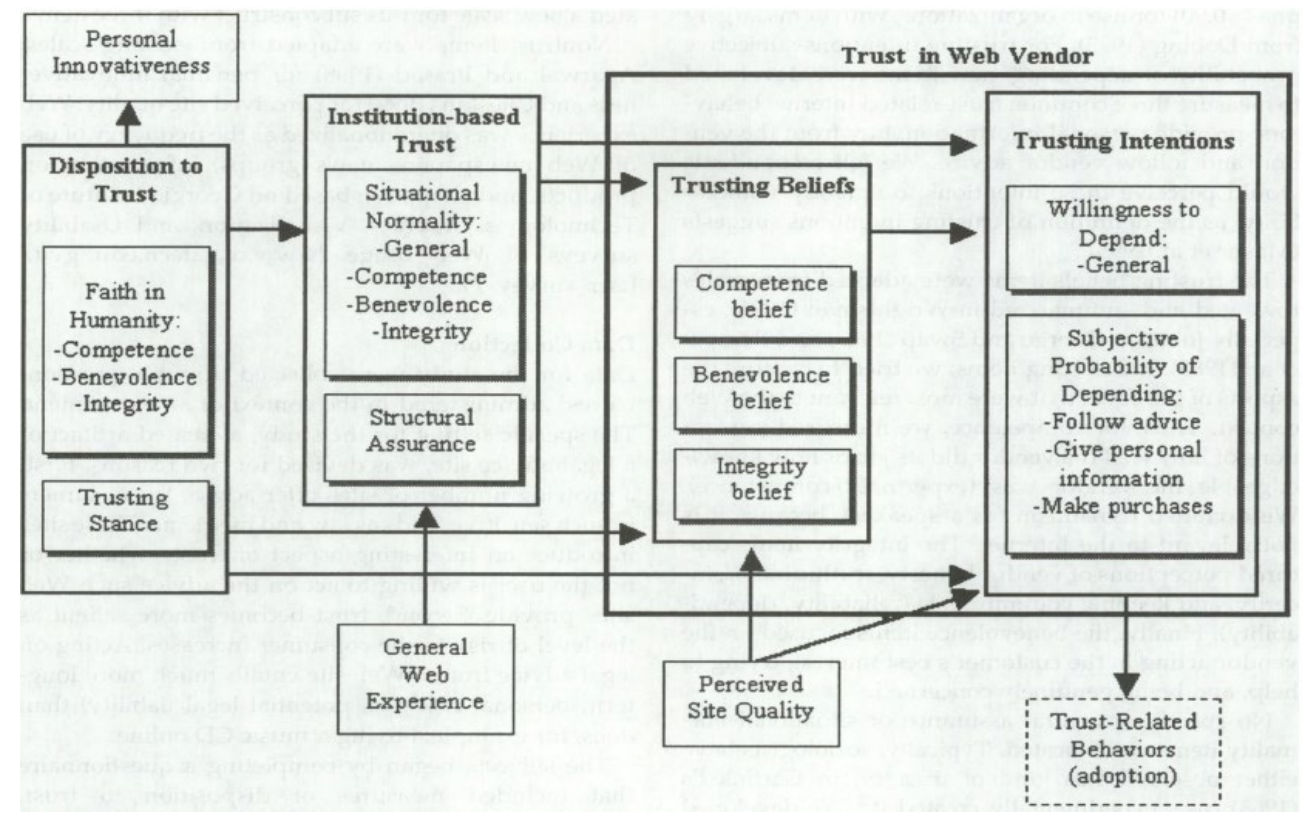

Figure 1: The trust model in e-commerce (McKnight et al., 2002, p. 341)

Differently, Siau and Shen (2003) argued that the process of developing the trust of ecommerce customers is dynamic and time-consuming, thus they proposed two types of trust namely, initial and ongoing trust. When customers begin to conduct their first transactions, initial trust starts with merchants, which may be first based on information gathered about advantages, such as, convenience or cost efficiency, and reward attraction. Then continuous trust follows, which may result in forming firm consumer loyalty is developed once customers are convinced to buy further products/services or repeat transactions. Customers then evaluate their satisfaction, which given their repeat business must have included positive experiences with vendors. In contrast, if customers have a bad experience, this could result in them dropping out due to distrust of the merchants. Figure 2 illustrates the impact of customer loyalty on consumer behaviour.

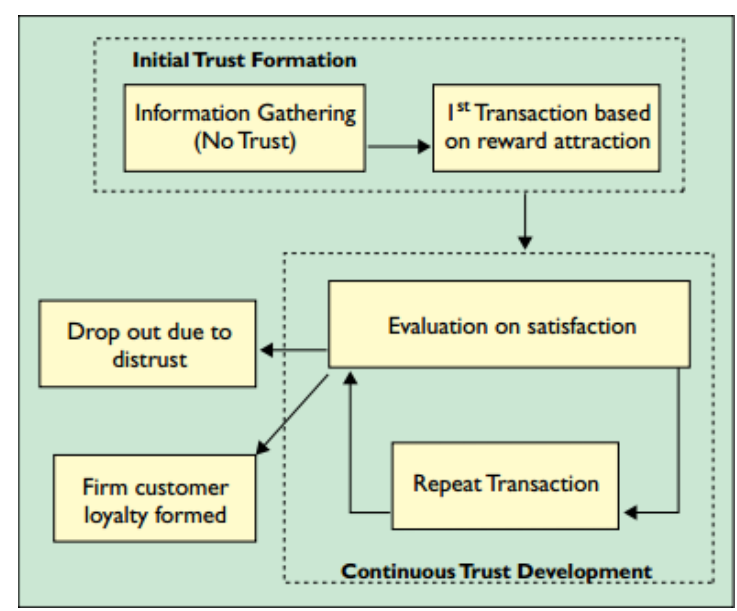

Figure 2: The e-commerce trust development life cycle (Siau \& Shen, 2003, p. 92) 
Siau, Sheng, and Nah (2003) suggested a framework for trust in m-commerce with five groups of factors including vendor and website characteristics, technology of wireless services and mobile devices and other factors, such as, legal regulations or third-party certification. Figure 3 illustrates the framework for trust in m-commerce (Siau et al., 2003, p. 88).

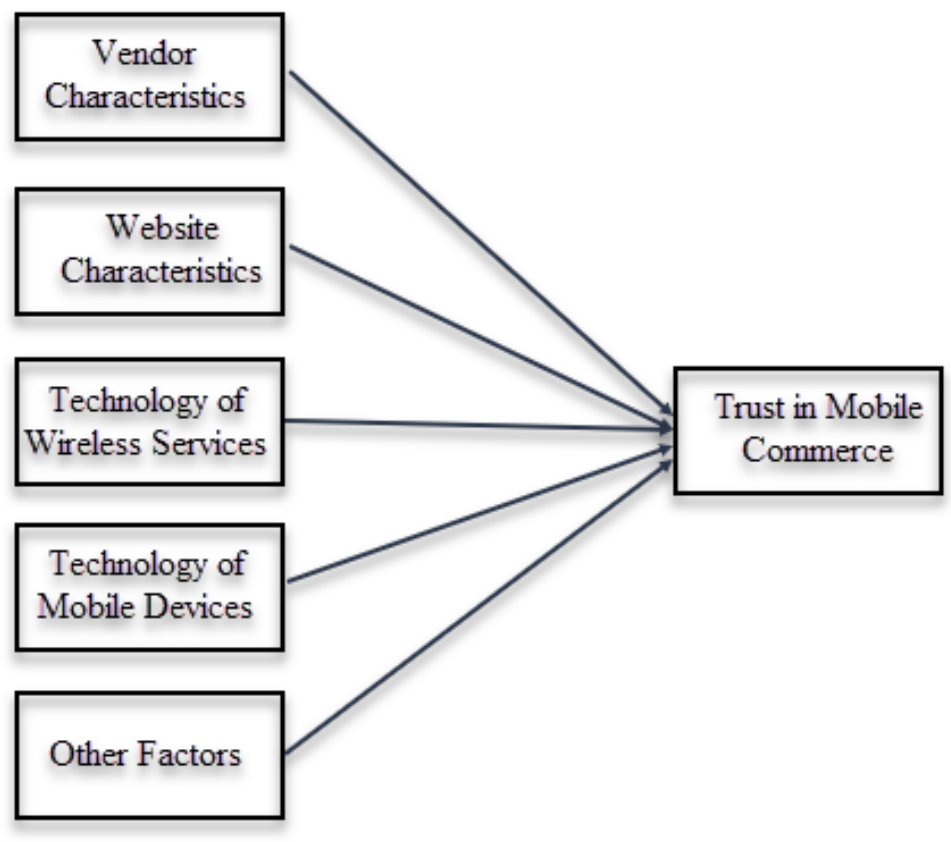

Figure 3. Proposed framework for trust in m-commerce (Siau et al. 2003, p. 88)

More broadly, Siau and Shen (2203, p. 92) proposed two components for building customer trust in m-commerce which are mobile technology and mobile vendor trust (see Figure 4).

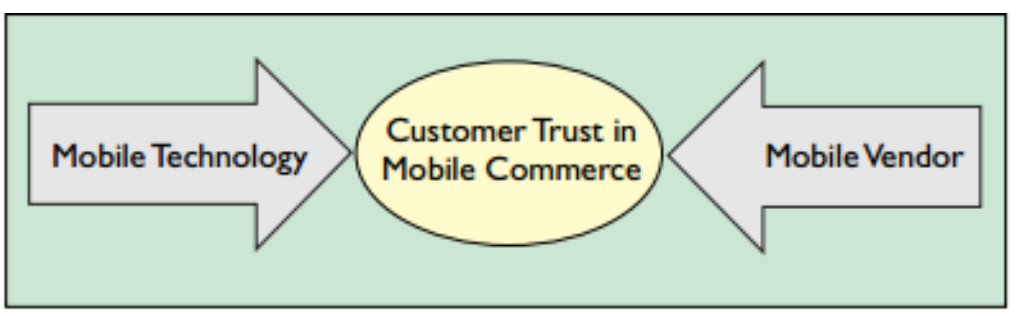

Figure 4:. Framework for m-commerce trust building (Siau and Shen 2003, p. 92)

A lack of trust has been recognised as a major obstacle for any m-commerce service (Chen \& Dhillon, 2003; Joubert \& Belle, 2009). M-payment is a significant component of m-commerce services as it allows mobile users to conduct financial transactions to finish their $\mathrm{m}$-commerce transactions. Trust plays an important role in m-payment adoption therefore it has been studied in many m-payment studies (e.g. Gao \& Waechter, 2017; Hillman \& Neustaedter, 2017; Nguyen et al., 2020; Patil et al., 2018; Qasim \& Abu-Shanab, 2016; Slade, Dwivedi, Piercy, \& Williams, 2015; Xin et al., 2015).

Most previous studies examined the effect of trust as a single construct on intention to adopt $\mathrm{m}$-payment services without the identification of which types of trust constituting overall trust of m-payment consumers (Nguyen et al., 2020). Many authors adopted the Unified Theory of Acceptance and Use of Technology (UTAUT) or Technology Acceptance Model (TAM) as a theoretical underpinning of their research project involving trust as a predictor of m-payment 
adoption (e.g. Andreev et al., 2012; Liu, 2012; Mingxing, Jing, \& Yafang, 2014; Zhou, 2013). Zhou (2011) adopted TAM and Diffusion of Innovation Theory (DOI) to investigate the effect of initial trust on user adoption of m-payment services, in China, and recognised the significant effect of perceived ubiquity, security and ease of use on initial trust which positively influence m-payment usage intention. When researching drivers of the willingness to use m-payment in Israel, Andreev et al. (2012) extended TAM and included DOI, and found a direct and significant impact of vendor trust, and a non-significant impact of mechanism trust on willingness to use m-payment services. Similarly, based on TAM and DOI, Liu (2012) collected data from 200 university students in Jiangsu, China to test consumers' intention to use m-payment services. The outcome indicated that trust is one of the most important variables affecting intention to adopt m-payment services. Mingxing et al. (2014) refined factors from TAM and recognised the important effect of customers' perceived risk and trust on m-payment adoption in China.

Yan and Yang (2014) used TAM2 to empirically examine user adoption of m-payments in China, and recognised the vital effect of perceived ease of use, perceived usefulness, structural assurance, and ubiquity on trust, and the impact of trust on m-payment adoption. Phonthanukitithaworn, Sellitto, and Fong (2015) extended TAM to test user intentions to adopt m-payment services in Thailand and found that perceived trust had a significant positive influence on behavioural intention. The study of Slade, Williams, Dwivedi, and Piercy (2015) underpinned by UTAUT2, and collected data in the UK, revealed that trust was an important predictor for intention to adopt m-payment services. Based on UTAUT and TAM, Qasim and Abu-Shanab (2016) examined the impact of network externalities, such as, performance and effort expectancy, social influence, and trust on m-payment acceptance in Jordan. Except for effort expectancy, their study found all factors were significant. Gao and Waechter (2017) integrated TAM, UTAUT and the valence framework by Peter, Sr, and X (1975) which is a customer decision-making model examining customer behaviour to argue that a lack of trust was the most significant long-term inhibitor for acceptance and success of $\mathrm{m}$-payment services. Then they examined the role of initial trust developed by consumers when interacting with mpayments for the first time on perceived benefit and convenience which in turn influenced intention to adopt m-payment. Gao and Waechter collected data from a sample in Australia, and revealed that perceived system quality, information quality and service quality also positively and significantly influence initial trust, which positively impacts intention to adopt m-payment.

Besides UTAUT and TAM, numerous authors have used other theoretical framework and also recognised the significant impact of trust on m-payment adoption without the consideration of types of trust in the context of m-payment adoption (Huang \& Liu, 2012; Jia, Hall, \& Zhu, 2015; Lu, Yang, Chau, \& Cao, 2011; Xin et al., 2015; Zhou, 2013, 2014). Based on the literature of the concern for information privacy and Internet users' information privacy concerns, Huang and Liu (2012) investigated the effect of Internet users' concern for information privacy on intention to adopt m-payment in China, and found a significant positive impact of control, awareness and collection on trust and intention to use m-payment. Lu et al. (2011) adopted the valence framework by Peter et al. (1975) to develop a trust-based customer decision-making model and examined how trust interacted with both positive and negative factors. They found that initial mobile payment trust had a significant positive impact on behavioural intention, and a significant negative impact on perceived risk. Zhou (2013) used the Information Systems Success model (ISS) (Delone \& McLean, 2003) as a theoretical basis to identify the factors 
influencing continuance intention to adopt m-payment in China. He found a positive and significant effect of the system, information and service quality on trust which has an important impact on continuing intention to adopt m-payment. Similarly, based on ISS, Zhou (2014) examined the determinants of m-payment adoption in China. The results confirmed that system and information quality are significant antecedents for trust in m-payment, which in turn influences adoption.

Jia et al. (2015) utilised a multi-stage decision making model and initial trust building theory to explore how trust is built into the learning process of customers in China, and the effect of trust on intention to use m-payment. The result indicated that exposure to m-payment and information searching has a significant and positive impact on trust which positively influences individual behavioural intention. Xin et al. (2015) collected data in New Zealand to examine the determinants of trust. The model confirmed the significant impact of perceived reputation of mobile service provider, perceived opportunism of mobile service provider, reputation of mobile payment vendor, structural assurance, environment risk, espoused uncertainty avoidance, and disposition to trust on trust in m-payment adoption, nonetheless it still neglected the different types of trust that constitute trust of m-payment consumers.

Trust is a complex concept, therefore it should be theorised as a multidimensional or multifaceted phenomenon (Chen \& Dhillon, 2003; Hillman \& Neustaedter, 2017; Jimenez et al., 2016; McKnight et al., 2002; Meng et al., 2008; Yan, Niemi, Dong, \& Yu, 2008). Researchers have pointed out that exploring the different types of trust in $\mathrm{m}$-commerce is beneficial to a better understanding of trust, leading to more substantial understanding and prediction of consumer adoption (Meng et al., 2008; Min et al., 2008; Nguyen et al., 2020). As a result, research on trust in m-payment adoption needs to identify trust types and their interaction effects on m-payment adoption (Nguyen et al. 2020). This could lead to a more comprehensive understanding of the concept of trust in the context of m-payment adoption, such as, understanding the trust dimensions and how they affect each other and to the intention to adopt m-payment. We argue that the overall consumer trust towards m-payment services can act as a mediating factor between trust types and m-payment adoption.

\subsection{Research Aim and Questions}

This study aims to identify different types of trust that constitute trust of m-payment consumers and whether consumer trust mediates the effect of trust types and m-payment adoption. This leads to the following research questions:

- What are the relevant types of trust in adopting m-payment?

- To what extent does consumer trust mediate the relationship between identified trust types and m-payment adoption?

\section{The Proposed Model and Hypotheses}

Regarding identifying the trust types that constitute consumer trust in m-payment context, the authors conducted a comprehensive review of related literature regarding trust in the adoption of e-commerce, $\mathrm{m}$-commerce, mobile banking, and $\mathrm{m}$-payment. This is because: (1) m-payment is considered a subset of m-commerce, as well as, e-commerce, and mobile banking applications also can be used for the purpose of m-payment; (2) there is no agreement regarding the types of trust in m-payment adoption. Obviously, a comprehensive review of 
related literature was necessary. Based on this review, the authors adopted four sub-types of trust in the context of m-payment adoption as following.

M-payment provider trust refers to the belief of consumers that the m-payment service provider will perform and complete the transactional commission, as well as, any obligations which might arise from risky or uncertain circumstances (Joubert \& Belle, 2009, 2013), i.e. the extent to which consumers trust the m-payment provider. This is important in the context of mpayment because an m-payment service provider approaches, uses and stores private and important consumer information, such as, personal and financial information, bank account data, and data about purchased goods and services. Obviously, in order to use m-payment, consumers must be confident that $\mathrm{m}$-payment providers are able to provide and process $\mathrm{m}$ payment services correctly, fast, conveniently, and securely (Mingxing et al., 2014).(Mingxing et al. 2014). Service provider trust plays an important part in the overall trust of consumers, therefore it is widely used in research on e-commerce adoption (McKnight \& Chervany, 2001a, 2001b; McKnight et al., 2002; McKnight, Kacmar, \& Choudhury, 2004), m-commerce adoption (Joubert \& Belle, 2009, 2013; Meng et al., 2008; Min et al., 2008; Siau \& Shen, 2003; Siau, Sheng, Nah, \& Davis, 2004), and m-payment adoption (Mingxing et al., 2014; Srivastava, Chandra, \& Theng, 2010; Xin et al., 2015). As a result, the authors suggest m-payment provider trust is the first type of trust in building consumer trust in m-payment services. This leads to the following hypothesis:

H1: M-payment provider trust positively influences consumer trust in m-payment.

Technology trust or system trust refers to the degree to which consumers believe that the underlying technology or system has the ability to work as expected and to process mpayment transactions appropriately (Joubert \& Belle, 2013).(Joubert and Belle 2013). This study looks at system/technology trust from the viewpoint of consumers, instead of technical and technological specialists. Many authors have identified the significant role of technology trust on m-commerce (Joubert \& Belle, 2009, 2013; Meng et al., 2008; Min et al., 2008; Siau \& Shen, 2003; Siau et al., 2003), and m-payment adoption (Srivastava et al., 2010). The underlying technology in m-payment includes not only the application technology of the m-payment provider, but also other involved technologies such as Internet bandwidth, network connection coverage, mobile devices technology, encryption, mobile operating systems, connection technology such as NFC, and banking systems that accept financial transactions (Cabral, 2018; Krishnan, 2015). Consequently, technology trust differs from m-payment provider trust, and should be recognised as a separate type of trust in m-payment adoption. As a result, the authors argue that if consumers think that m-payment related technology is trustworthy, they are more likely to trust m-payment. This leads to the following hypothesis.

H2: Technology trust positively influences consumer trust in m-payment.

Institution-based trust refers to the belief of consumers that necessary structural conditions for increasing the likelihood of achieving a successful outcome in an endeavour like m-payment, are present (Joubert \& Belle, 2013; McKnight et al., 2002). Institution-based trust includes two dimensions: structural assurance and situational normality. Structural assurance manifests the belief that structures, such as, guarantees, promises, regulations, and legal resources are accessible to ensure the success and security of transactions (McKnight et al., 2002). Situational normality refers to the belief that the online environment is appropriate, well ordered, and favourable for conducting transactions (McKnight \& Chervany, 2001a). Cheung and Lee (2001) pointed out that institutional infrastructure and regulations are the critical determinants for 
building customer trust. Mahadevan and Venkatesh (2000) explained the power of institutionbased trust that the legal system plays an essential role in regulating the vendors to provide fair information and protect user's privacy and other concerns, thereby recovering customers' confidence and belief. Pavlou and Gefen (2004, p.37) stated that "Institution-based trust is a buyer's perception that effective third-party institutional mechanisms are in place to facilitate transaction success". Due to the importance of institution-based trust, it has been widely adopted in research on e-commerce (Gefen, Karahanna, \& Straub, 2003; McKnight et al., 2002; Pavlou \& Gefen, 2004), m-commerce (Cho, Kwon, \& Lee, 2007; Guangming \& Yuzhong, 2011; Hillman \& Neustaedter, 2017; Joubert \& Belle, 2009, 2013; Min et al., 2008; Piao et al., 2012), mobile banking (Nguyen, 2016), and m-payment (Hillman \& Neustaedter, 2017; Srivastava et al., 2010; Yan \& Yang, 2014). As a result, the authors argue that if consumers perceive that they are protected by third-party institutional mechanisms when using m-payment, they are more likely to trust m-payment. This results in the following hypothesis.

H3: Institution-based trust positively influences consumer trust in m-payment.

Seller trust is the degree to which the consumer trusts a community of sellers, and this is necessary for any e-commerce, as well as, social commercial activities (Lu et al., 2016). Seller trust is a vital factor in $\mathrm{m}$-commerce because in the online environment, sellers and buyers may make contact anonymously, and normally conduct transactions without a formal contractual agreement (Andreev et al., 2012). The significant role of seller trust is identified in many studies on e-commerce, as well as, m-payment adoption (Andreev et al., 2012; Lu et al., 2016; Pavlou \& Gefen, 2004). Pavlou and Gefen (2004) collected data from Amazon's auction websites, and demonstrated the significant impact of trust in sellers on the transaction intention of customers in online markets. Lu et al. (2016) found the important effect of trust in sellers on social commerce purchase intention of customers in China. The study of Andreev et al. (2012) collected data in Israel, and resulted in showing the significant influence of trust in sellers on willingness to use m-payments. Obviously, a reputable seller must not only provide qualified goods, but also use a fast, accurate and secured payment method. As a result, the authors argue that if consumers trust reputable sellers who accept and use m-payment for their goods or services, consumers are more likely to trust m-payment. This leads to the following hypothesis.

H4: Seller trust positively influences consumer trust in m-payment.

Prior studies empirically found that consumer trust is one of the important drivers for $\mathrm{m}$ payment adoption (Patil et al., 2018; Qasim \& Abu-Shanab, 2016; Xin et al., 2015), therefore the authors put forward that if consumers trust m-payment, they are more likely to intend to adopt $\mathrm{m}$-payment services in conducting e-commerce transactions. This leads to the last hypothesis.

H5: Consumer trust in m-payment positively influences intention to adopt m-payment.

Figure 5 presents the proposed model and hypotheses of this research: 


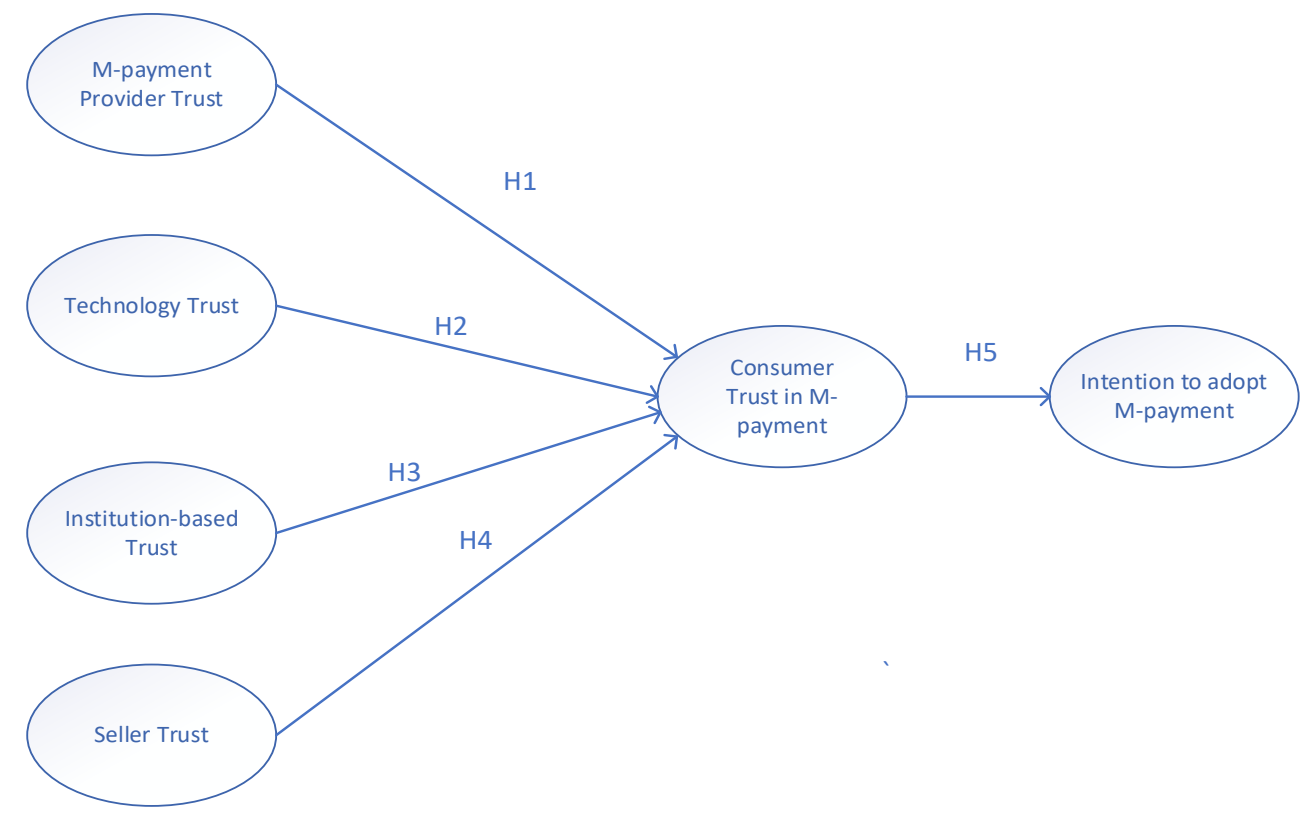

Figure 5. The proposed model

\section{Research Methodology}

This section discusses the design of instrument and data collection.

\subsection{Instrument Development}

The construct instruments for the questionnaire used for data collection were borrowed from previous studies which had been tested and validated (see Table 1). All questions were translated to Vietnamese and then revised based on the pilot test. Participants indicated their agreement or disagreement with the questions in the online survey (see Appendix 8.1 for full survey questions).

\begin{tabular}{|l|l|}
\hline Construct and Items & References \\
\hline M-payment provider trust (PT): six items & $\begin{array}{l}\text { Andreev et al. 2012; Srivastava et al. 2010; } \\
\text { Zhou 2011 }\end{array}$ \\
\hline Technology trust (TT): four items & Srivastava et al. 2010 \\
\hline Institution-based trust (IT): six items & $\begin{array}{l}\text { McKnight et al. 2002; Nguyen 2016; } \\
\text { Srivastava et al. 2010 }\end{array}$ \\
\hline Seller trust (ST): four items & $\begin{array}{l}\text { Andreev et al. 2012; Lu et al. 2016; Pavlou } \\
\text { and Gefen 2004 }\end{array}$ \\
\hline Consumer trust (CT): four items & Lu et al. 2011; Qasim \& Abu-Shanab 2016 \\
\hline Intention to adopt m-payment (IN): three items & Venkatesh et al. 2012 \\
\hline
\end{tabular}

Table 1. Instrument items used in the survey

\subsection{Data Collection}

In order to test the hypotheses, data was collected in Vietnam using survey, targeting the population that: (1) are over 18 years old, and (2) have used m-payment services in the last three months. An online survey with the questionnaire in the Vietnamese language was hosted in Qualtrics survey tool. The pilot test was conducted with a group of $31 \mathrm{~m}$-payment users to refine the items, and the pilot test data was not included in the final data. The authors used a Facebook account to promote the survey to participants. Given the fact that using m-payment is voluntary and popular amongst Vietnamese consumers, the connections in the social 
network were effective in approaching participants without raising concerns about spam, virus or spyware when accessing the online survey. The measurement model includes 28 questions therefore with a rate of case-to-variables of 5:1 for factor analysis (Hair, Black, Babin, Anderson, \& Tatham, 1998), the needed sample is at least 140 observations. A total of 225 answers was collected over two months. After checking outlier and missing data, 204 valid observations were used for further analysis, which satisfies the sample adequacy criterion.

Of the survey participants, $72 \%$ were female and $28 \%$ male. Nearly $97 \%$ were with a degree or above, $71 \%$ aged under 35 years old, with $94 \%$ had used smart phones for more than three years. All participants had experience of using some forms of m-payment before. See Appendix 8.2 for full demographic information.

The data was tested for common method bias by using Harman's test (Chau, Deng, \& Tay, 2020; Podsakoff, MacKenzie, Lee, \& Podsakoff, 2003), which revealed that the largest factor explains only $13.56 \%$ of the variance in the measure. This is less than $50 \%$ the threshold of common method bias, so there is no significant common method bias in the data.

As there were significantly more female respondents, the data was examined for potential bias between male and female via conducting a two-sample t-test with six constructs adopted in the conceptual model. The independent $\mathrm{t}$-test results revealed that there is no significant difference between male and female at a 95\% confidence level for the variables. This is consistent to the previous study of Xin et al. (2015) which found that gender has insignificant impact on trust in m-payment adoption. Overall, it is unlikely that the results are biased by gender.

\section{Data Analysis and Results}

Structural Equation Modelling (SEM) is a general term that refers to a multivariate statistical analysis technique used to evaluate and analyse the structural relationship between the latent variables and their measured variables with empirical data. This study used SPSS and SmartPLS to analyse the collected data including 204 responses. Analysis was done in two steps: the reliability and validity assessment of the measurement model were tested, and the structural model assessment performed which are presented below.

\subsection{Measurement Model}

There are four criteria to test the measurement model which are construct, indicator, convergence and discriminant validity. Construct validity is tested via composite reliability and Cronbach's alpha with the cut-off value is 0.7 (Straub, 1989). An item that has factor loading lower than 0.4 must be eliminated for indicator validity (Churchill, 1979). The requirement for convergence validity is the average variance extracted (AVE) is greater than 0.5 (Henseler, Ringle, \& Sinkovics, 2009). Discriminant validity is tested by the HTMT analysis with the cut-off value is 0.85 (Ab Hamid, Sami, \& Sidek, 2017; Kline, 2015).

Based on the above criteria, the authors dropped items IT1, PT4 due to a low factor loading, and the technology trust (TT) construct due to high loading on the m-payment provider trust (PT) construct. The implication of this elimination is discussed in the section 6.2. All the remaining items and constructs met the requirements of validity for measurement model. The outcome is presented in Tables 2 and 3. 


\begin{tabular}{|c|c|c|c|c|c|}
\hline Construct & Cronbach's alpha & Composite reliability & AVE & Items & Loading \\
\hline \multirow{3}{*}{$\begin{array}{l}\text { Intention to adopt m- } \\
\text { payment (IN) }\end{array}$} & \multirow[t]{3}{*}{0.777} & \multirow[t]{3}{*}{0.785} & \multirow[t]{3}{*}{0.649} & IN1 & 0.7 \\
\hline & & & & IN2 & 0.717 \\
\hline & & & & IN3 & 0.885 \\
\hline \multirow[t]{4}{*}{ Customer trust (CT) } & \multirow[t]{4}{*}{0.894} & \multirow[t]{4}{*}{0.894} & \multirow[t]{4}{*}{0.678} & CT1 & 0.806 \\
\hline & & & & CT2 & 0.843 \\
\hline & & & & CT3 & 0.8 \\
\hline & & & & CT4 & 0.844 \\
\hline \multirow{5}{*}{$\begin{array}{l}\text { Institution-based trust } \\
\text { (IT) }\end{array}$} & \multirow[t]{5}{*}{0.902} & \multirow[t]{5}{*}{0.898} & \multirow[t]{5}{*}{0.642} & IT2 & 0.975 \\
\hline & & & & IT3 & 0.78 \\
\hline & & & & IT4 & 0.718 \\
\hline & & & & IT5 & 0.727 \\
\hline & & & & IT6 & 0.777 \\
\hline \multirow{5}{*}{$\begin{array}{l}\text { M-payment provider } \\
\text { trust }(\mathrm{PT})\end{array}$} & \multirow[t]{5}{*}{0.901} & \multirow[t]{5}{*}{0.902} & \multirow[t]{5}{*}{0.648} & PT1 & 0.753 \\
\hline & & & & PT2 & 0.842 \\
\hline & & & & PT3 & 0.878 \\
\hline & & & & PT5 & 0.829 \\
\hline & & & & PT6 & 0.713 \\
\hline \multirow[t]{4}{*}{ Seller trust (ST) } & \multirow[t]{4}{*}{0.91} & \multirow[t]{4}{*}{0.909} & \multirow[t]{4}{*}{0.715} & ST1 & 0.89 \\
\hline & & & & ST2 & 0.824 \\
\hline & & & & ST3 & 0.863 \\
\hline & & & & ST4 & 0.802 \\
\hline
\end{tabular}

Table 2. Validity criteria and factor loadings

Table 3 presents the outcome of HTMT analysis which indicates that the requirement of discriminant validity is satisfied with the cut-off value is 0.85 (Ab Hamid et al., 2017; Kline, 2015).

\begin{tabular}{|l|l|l|l|l|l|}
\hline & CT & IN & IT & PT & ST \\
\hline CT & & & & & \\
\hline IN & 0.581 & & & & \\
\hline IT & 0.785 & 0.404 & & & \\
\hline PT & 0.775 & 0.416 & 0.816 & & \\
\hline ST & 0.794 & 0.396 & 0.747 & 0.712 & \\
\hline
\end{tabular}

Table 3. Discriminant validity with HTMT Analysis

The requirements of the model fit measurement are satisfied based on the criteria of $\mathrm{Hu}$ and Bentler (1999) and are shown in the Table 4 below.

\begin{tabular}{|l|l|l|l|}
\hline Measure & Estimate & Threshold & Interpretation \\
\hline CMIN/DF & 2.830 & Between 1 and 3 & Excellent \\
\hline CFI & 0.901 & $>0.95$ & Acceptable \\
\hline SRMR & 0.071 & $<0.08$ & Excellent \\
\hline
\end{tabular}

Table 4. The model fit measures 


\subsection{Structural Model and Hypothesis Testing}

The structural model and hypotheses were tested based on the examination of standardized paths. The path relationship between three types of trust including m-payment provider, institution-based, seller, and customer trust are positive and significant with $\mathrm{p}<0.1, \mathrm{p}<0.05$, $\mathrm{p}<0.01$ (Baptista \& Oliveira, 2015), therefore hypotheses 1, 3 and 4 are supported. The effect of trust on intention to adopt m-payment is significant with $\mathrm{p}=0.000$ hence hypothesis 5 is supported. Hypothesis 2 is dropped as the TT construct is dropped due to high cross loading discussed before. The model explains a $74.1 \%$ and $33.5 \%$ of variation in consumer trust in mpayment and intention to adopt m-payment, respectively. The overall outcome of structural model and hypothesis testing is indicated in the Tables 5 and Figure 6 below:

\begin{tabular}{|l|c|c|c|c|l|}
\hline Hypothesis & $\begin{array}{l}\text { Original } \\
\text { Sample (O) }\end{array}$ & $\begin{array}{l}\text { Standard Deviation } \\
\text { (STDEV) }\end{array}$ & $\begin{array}{l}\text { T Statistics } \\
\text { (IO/STDEVI) }\end{array}$ & P Values & Results \\
\hline H1: PT -> CT & 0.25 & 0.131 & 1.914 & 0.056 & Supported \\
\hline H3: IT -> CT & 0.29 & 0.123 & 2.361 & 0.019 & Supported \\
\hline H4: ST -> CT & 0.399 & 0.098 & 4.071 & 0.000 & Supported \\
\hline H5: CT -> IN & 0.579 & 0.066 & 8.835 & 0.000 & Supported \\
\hline
\end{tabular}

Table 5. The path coefficients of hypotheses

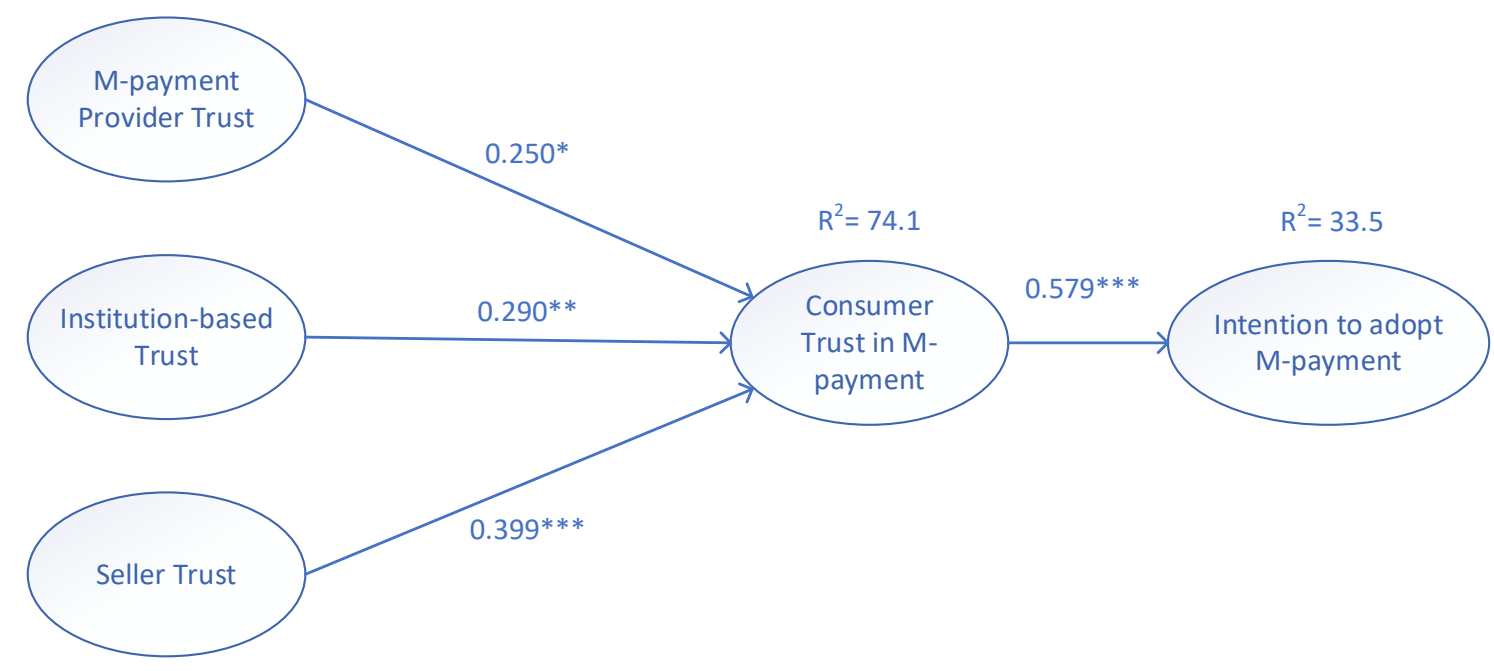

Note: $\left({ }^{*} p<0.1 ; * * p<0.05 ; * * * p<0.01\right)$

Figure 6. Structural model results

Regarding the mediating impact of consumer trust, the direct impact of the three types of trust on intention to adopt m-payment was conducted and found no significant relationship as shown in Table 6. As a result, consumer trust has a full mediating impact on the relationship between the three types of trust and m-payment adoption.

\begin{tabular}{|l|l|l|l|l|l|}
\hline & $\begin{array}{l}\text { Original } \\
\text { Sample (O) }\end{array}$ & $\begin{array}{l}\text { Standard Deviation } \\
\text { (STDEV) }\end{array}$ & $\begin{array}{l}\text { T Statistics } \\
(\mid \text { O/STDEVI) }\end{array}$ & P Values & Results \\
\hline IT -> IN & 0.037 & 0.404 & 0.093 & 0.926 & Not supported \\
\hline PT -> IN & -0.066 & 0.26 & 0.253 & 0.8 & Not supported \\
\hline ST -> IN & -0.18 & 0.168 & 1.068 & 0.286 & Not supported \\
\hline
\end{tabular}

Table 6. The path coefficients of direct relationship between trust types and intention to adopt mpayment 


\section{Discussion}

This section discusses the findings, research and practical contributions, and limitation of this study.

\subsection{Trust Types and Mediating Effect of Consumer Trust}

The study found a significant positive effect for m-payment provider trust, institution-based trust and seller trust on the overall consumer trust in m-payment. The variance explained of consumer trust in m-payment is $74.1 \%$ which can be classified as substantial (Chin, 1998). The positive effect of m-payment provider trust on consumer trust is consistent with earlier research which recognised the important role of the service provider in e-commerce, $\mathrm{m}$ commerce, and m-payment (Joubert \& Belle, 2009; McKnight et al., 2002; Mingxing et al., 2014). The institution-based trust impact finding is also supported in earlier research (McKnight et al., 2002; McKnight et al., 2004; Nguyen, 2016). Obviously, consumers consider that the protection of third-party mechanisms are vital to use m-payment services. The relationship between seller trust and consumer trust in m-payment is also confirmed, which is in line with earlier research ( $\mathrm{Lu}$ et al., 2016; Pavlou \& Gefen, 2004; Siau et al., 2004). Accordingly, consumers believe in choosing the m-payment method when it is used by reputable sellers. Finally, the significant impact of consumer trust on intention to adopt m-payment is also validated, which is consistent with previous studies (Patil et al., 2018; Qasim \& Abu-Shanab, 2016; Xin et al., 2015). This confirms the role of consumer trust as a key driver for m-payment adoption.

In the data analysis, technology trust (TT) construct was dropped due to high cross loading and inter-correlation on provider trust (PT), hence hypothesis 2 was not assessed. This means $\mathrm{m}$-payment TT overlaps with $\mathrm{m}$-payment PT. This may be because the underlying technology of m-payments such as encryption, network security, and mobile technology in the financial system are too complex for customers to comprehend and establish trust. As a result, consumers consider that the m-payment provider should be fully responsible for the technology assurance of m-payment services. This finding is a new characteristic of $\mathrm{m}$ payment adoption which is different from the adoption of traditional e-commerce and $\mathrm{m}$ commerce found in the literature. M-payment consumers should not be required to clearly understand the technology and its security aspects, but rather they rely on m-payment providers as part of their service commitment to ensure the transactions will be secure and safe. Accordingly, this also highlights the important role of the m-payment provider since from the consumer perspective, the quality of m-payment technology is the responsibility of the m-payment provider.

Another important finding is the significant full mediating effect of consumer trust on the relationship between three types of trust and intention to adopt m-payment. This result indicates that consumer trust can be affected by many factors, and it plays a mediating role that leads to m-payment adoption decision. It is important to notice that having established consumer confidence in various aspects of the m-payment service is not sufficient for adopting the service. Provider trust, institution trust or seller trust alone does not guarantee consumers to consider m-payment, the overall consumer trust as of result of developing trust types plays a critical role in influencing the corresponding behaviour. 


\subsection{Contributions}

M-payment is a state-of-the-art payment method which plays an important role in the evolution of payment for society from cash to digital methods of payment, especially post COVID-19 where touchless or low-touch economy becomes a must. Consumer trust is a significant driver of $\mathrm{m}$-payment adoption and understanding trust can help to predict as well as increase the adoption of m-payment. As a result, the results of this study have important implications for both research and practice.

For researchers, this study provides the classification and recognition of three types of trust including m-payment provider, institution-based and seller trust which have significant impacts on trust of m-payment consumers. It also separates overall consumer trust from other context-specific trusts. This could lead to a call for further research such as exploring further determinants of consumer trust or trust types, investigating the relationship between each type of trust and other critical factors in m-payment adoption, examining, how consumer trust's mediating role changes with different trust determinants, or with various levels of consumer awareness. Future research can measure or employ trust of consumers as a reflective construct with these three trust types in the context of m-payment adoption. In addition, these three types of trust can be extended to study further in adopting of other technologies.

For practitioners, the study's findings explain working mechanism of trust on using the service. It identifies clearly significant types of trust to refine, promote, and implement $\mathrm{m}$ payment services that can be more likely accepted by consumers. M-payment providers can cooperate with reputable sellers and convince them to accept using m-payment for their goods or services. When m-payment is adopted in famous e-markets with reputable sellers, consumers may be more likely to buy or sell on the market. From a customer perspective, the m-payment provider is fully responsible for not only the quality but also the technology assurance of m-payment service, thus m-payment providers must focus on improving their applications to operate well in different conditions regarding mobile operating systems, networking, speed connection, and security. Policy makers need to enact regulations or mechanisms to protect the legal rights of m-payment customers, and clearly specify the responsibility of stakeholders such as m-payment providers, banks, and financial institutions. This contributes to the customers' perception of overall safety when using m-payment, leading to high use m-payment or m-commerce. When the three types of trust are consolidated for consumers, they are also more likely to trust and adopt m-payment.

The understanding of the role of consumer trust also highlights and expands current findings in both theory and practice. This study not only confirms the significant impact of trust on intention to adopt m-payment, but also recognise the full mediating role of trust of consumers. Trust accounts for all of the effects of the three types of trust including m-payment provider, institution-based and seller trust on m-payment adoption. Accordingly, when trust is enhanced, the impact of the three types of trust on m-payment adoption is also increased.

\subsection{Limitations}

There is a limitation to this research that needs to be acknowledged. The data sample of 204 respondents is limited to the social connection of the authors, which may have led to a potential bias in the data. Future research should collect more data with a wider population scope. 


\section{Conclusion}

The benefits of m-payment are obvious for both business and consumers such as the convenience, security, better tracking of transactions, a safer way of payment especially in the contemporary situation of COVID-19 spread worldwide. As a result, m-payment is considered as a useful modern tool that is being adopted worldwide. This research aims to address the lack of understanding of the different types of trust that constitute trust of consumers in $\mathrm{m}$ payment adoption. The proposed model was tested with data collected in Vietnam which has one of the world's fastest m-payment adoption rates. This paper validated the model identifying three relevant types of trust which are m-payment provider trust, institution-based trust and seller trust as constituting consumer trust in m-payment. The data analysis also revealed that technology trust could be embedded in m-payment provider trust perceived by consumers. This study found that consumer trust is a full mediator for the relationship between the three trust types and intention to adopt m-payment of consumers. The outcome can be used for better understanding of trust in m-payment, which contributes not only to researchers regarding the literature of trust in m-payment adoption as well as technology adoption, but also to practitioners such as managers, m-payment service providers, and consultants to enhance consumer trust when promoting m-payment and other technologies.

\section{References}

Ab Hamid, M., Sami, W., \& Sidek, M. M. (2017). Discriminant Validity Assessment: Use of Fornell \& Larcker Criterion Versus Htmt Criterion. Journal of Physics: Conference Series, 890(1), 012163.

Alalwan, A. A., Dwivedi, Y. K., \& Rana, N. P. (2017). Factors Influencing Adoption of Mobile Banking by Jordanian Bank Customers: Extending Utaut2 with Trust. International Journal of Information Management, 37(3), 99-110.

Alhulail, H. (2018). An Investigation of Customers' Loyalty to Social Commerce Websites. (Doctor of Philosophy Doctorate), RMIT University, Accessed on 28/11/2018 from https://ap01.alma.exlibrisgroup.com/discovery/delivery/61RMIT_INST:RMITU/12248 274490001341

Andreev, P., Pliskin, N., \& Rafaeli, S. (2012). Drivers and Inhibitors of Mobile-Payment Adoption by Smartphone Users. International Journal of E-Business Research (IJEBR), 8(3), 50-67.

Asatryan, D. (2017). "Security and Lack of Trust Stall Mobile Payment Adoption." Accessed on 01/06/2019 from https://bankinnovation.net/2017/06/security-and-lack-of-truststall-mobile-payment-adoption/

Baptista, G., \& Oliveira, T. (2015). Understanding Mobile Banking: The Unified Theory of Acceptance and Use of Technology Combined with Cultural Moderators. Computers in Human Behavior, 50, 418-430.

Bilgihan, A. (2016). Gen Y Customer Loyalty in Online Shopping: An Integrated Model of Trust, User Experience and Branding. Computers in Human Behavior, 61, 103-113. doi:https://doi.org/10.1016/j.chb.2016.03.014

Cabral, J. (2018). "Mobile Payment Systems: Will Your Smart Phone Replace Your Wallet?". Accessed on 6/10/2019 from https://www.finder.com.au/mobile-payment-systems

Chau, N. T., Deng, H., \& Tay, R. J. J. o. M. M. (2020). Critical Determinants for Mobile Commerce Adoption in Vietnamese Small and Medium-Sized Enterprises. Journal of Marketing Management, 36(5-6), 456-487. 
Chen, S. C., \& Dhillon, G. S. (2003). Interpreting Dimensions of Consumer Trust in ECommerce. Information Technology and Management, 4(2-3), 303-318.

Cheung, C. M., \& Lee, M. K. (2001). Trust in Internet Shopping: Instrument Development and Validation through Classical and Modern Approaches. Journal of Global Information Management (JGIM), 9(3), 23-35.

Chin, W. W. (1998). Commentary: Issues and Opinion on Structural Equation Modeling. In. Management Information Systems Research Center, University of Minnesota: JSTOR.

Cho, D.-Y., Kwon, H. J., \& Lee, H.-Y. (2007). Analysis of Trust in Internet and Mobile Commerce Adoption. 40th Annual Hawaii International Conference on System Sciences (HICSS'07), 3-6 January, Waikoloa, Big Island, HI, 50-50.

Churchill, G. A. (1979). A Paradigm for Developing Better Measures of Marketing Constructs. Journal of Marketing Research, 16(1), 64-73.

Coyle, D. (2013). "The Cost of Mistrust." Accessed on 14/12/2020 from http://www.oecd.org/forum/the-cost-of-mistrust.htm

Delone, W. H., \& McLean, E. R. (2003). The Delone and Mclean Model of Information Systems Success: A Ten-Year Update. Journal of Management Information Systems, 19(4), 9-30.

Emily, S. (2018). "Different Types of Mobile Payments Explained." Accessed on 28/11/2020 from https://www.mobiletransaction.org/different-types-of-mobile-payments/

Fintechnews. (2018a). "Vietnam Fintech Sector Report: All About Digital and Mobile Payments ?". Accessed on 28/11/2018 from http://fintechnews.sg/20056/vietnam/vietnam-fintech-sector-report-mobile-paymentdigitial/

Fintechnews. (2018b). "Vietnam: Rise of E-Commerce Paving the Way for Digital, Mobile Payments Boom." Accessed on 16/12/2018 from http://fintechnews.sg/23211/mobilepayments/vietnam-rise-of-e-commerce-pavingthe-way-for-digital-mobile-payments-boom/

Fishbein, M., \& Ajzen, I. (1975). Belief, Attitude, Intention and Behavior: An Introduction to Theory and Research: Addison-Wesley, Reading, MA.

Gao, L., \& Waechter, K. A. (2017). Examining the Role of Initial Trust in User Adoption of Mobile Payment Services: An Empirical Investigation. Information Systems Frontiers, 19(3), 525-548.

Gefen, D., Karahanna, E., \& Straub, D. W. (2003). Trust and Tam in Online Shopping: An Integrated Model. MIS Quarterly, 27(1), 51-90.

Guangming, Y., \& Yuzhong, M. (2011). A Research on the Model of Factors Influencing Consumer Trust in Mobile Business. 2011 International Conference on E-Business and EGovernment (ICEE), 6-8 May 2011, Shanghai, China, 1-5.

Hair, J. F., Black, W. C., Babin, B. J., Anderson, R. E., \& Tatham, R. L. (1998). Multivariate Data Analysis (Vol. 5): Prentice Hall Upper Saddle River, NJ.

Hallikainen, H., \& Laukkanen, T. J. I. J. o. I. M. (2018). National Culture and Consumer Trust in E-Commerce. International Journal of Information Management, 38(1), 97-106.

Henseler, J., Ringle, C. M., \& Sinkovics, R. R. (2009). The Use of Partial Least Squares Path Modeling in International Marketing. In New Challenges to International Marketing (277319): Emerald Group Publishing Limited.

Hillman, S., \& Neustaedter, C. (2017). Trust and Mobile Commerce in North America. Computers in Human Behavior, 70, 10-21. 
Hu, L. t., \& Bentler, P. M. (1999). Cutoff Criteria for Fit Indexes in Covariance Structure Analysis: Conventional Criteria Versus New Alternatives. Structural Equation Modeling: A Multidisciplinary Journal, 6(1), 1-55.

Huang, Y., \& Liu, W. (2012). The Impact of Privacy Concern on Users' Usage Intention of Mobile Payment. 2012 International Conference on Information Management, Innovation Management and Industrial Engineering, 20-21 October 2012, Sanya, China, 90-93.

Jia, L., Hall, D., \& Zhu, S. (2015). Trust Building in Consumer Learning Process and Its Effect on Consumers' Behavioral Intention toward Mobile Payments. 21 ${ }^{\text {st }}$ Americas Conference on Information Systems, 13-15 August 2015, Fajardo, Puerto Rico.

Jimenez, N., San-Martin, S., \& Azuela, J. I. (2016). Trust and Satisfaction: The Keys to Client Loyalty in Mobile Commerce. Academia Revista Latinoamericana de Administración, 29(4), 486-510.

Joubert, J., \& Belle, J.-P. V. (2009). The Importance of Trust and Risk in M-Commerce: A South African Perspective. PACIS 2009 Proceedings, 96.

Joubert, J., \& Belle, J.-P. V. (2013). The Role of Trust and Risk in Mobile Commerce Adoption within South Africa. International Journal of Business, Humanities and Technology, 3(2), 2738.

Kline, R. B. (2015). Principles and Practice of Structural Equation Modeling. New York: Guilford Publications.

Kolaki, M. (2017). Mobile Payment Use and Mobile Payment Transactions by Older Adults: A Qualitative Study. (Master), Linnaus University, Accessed on 28/11/2020 from https://www.diva-portal.org/smash/get/diva2:1127590/FULLTEXT01.pdf

Kreyer, N., Pousttchi, K., \& Turowski, K. (2002). Standardized Payment Procedures as Key Enabling Factor for Mobile Commerce. Proceedings of the Third International Conference on E-Commerce and Web Technologies: Springer, 400-409.

Krishnan, A. (2015). "Technology Behind Mobile Payments." Accessed on 28/11/2020 from https://www.linkedin.com/pulse/technology-behind-mobile-payments-anandkrishnan

Lin, J., Wang, B., Wang, N., \& Lu, Y. (2014). Understanding the Evolution of Consumer Trust in Mobile Commerce: A Longitudinal Study. Information Technology and Management, 15(1), 37-49.

Liu, B. (2012). Understanding Consumers' Intention to Use Mobile Payment Services: The Perspective of University Students in Northern Jiangsu Area. 2012 Second International Conference on Business Computing and Global Informatization, 12-14 October 2012, Shanghai, China, 257-260.

Lu, B., Fan, W., \& Zhou, M. (2016). Social Presence, Trust, and Social Commerce Purchase Intention: An Empirical Research. Computers in Human Behavior, 56, 225-237. doi:https://doi.org/10.1016/j.chb.2015.11.057

Lu, Y., Yang, S., Chau, P. Y., \& Cao, Y. (2011). Dynamics between the Trust Transfer Process and Intention to Use Mobile Payment Services: A Cross-Environment Perspective. Information \& Management, 48(8), 393-403.

Mahadevan, B., \& Venkatesh, N. (2000). A Framework for Building Online Trust for Business to Business E-Commerce: Issues \& Challenges. IT Asia Millennium Conference, Bombay, India.

Malaquias, R. F., \& Hwang, Y. (2016). An Empirical Study on Trust in Mobile Banking: A Developing Country Perspective. Computers in Human Behavior, 54, 453-461. 
McKnight, D. H., \& Chervany, N. L. (2001a). Trust and Distrust Definitions: One Bite at a Time. In Trust in Cyber-Societies (27-54): Springer.

McKnight, D. H., \& Chervany, N. L. (2001b). What Trust Means in E-Commerce Customer Relationships: An Interdisciplinary Conceptual Typology. International Journal of Electronic Commerce, 6(2), 35-59.

McKnight, D. H., Choudhury, V., \& Kacmar, C. (2002). Developing and Validating Trust Measures for E-Commerce: An Integrative Typology. Information Systems Research, 13(3), 334-359.

McKnight, D. H., Kacmar, C. J., \& Choudhury, V. (2004). Dispositional Trust and Distrust Distinctions in Predicting High-and Low-Risk Internet Expert Advice Site Perceptions. e-Service Journal, 3(2), 35-58.

Meng, D., Min, Q., \& Li, Y. (2008). Study on Trust in Mobile Commerce Adoption-a Conceptual Model. 2008 International Symposium on Electronic Commerce and Security, 3-5 August 2008, Guangzhou City, China, 246-249.

Min, Q., Meng, D., \& Zhong, Q. (2008). An Empirical Study on Trust in Mobile Commerce Adoption. Proceedings of 2008 IEEE International Conference on Service Operations and Logistics, and Informatics IEEE/SOLI'2008, 659-664.

Mingxing, S., Jing, F., \& Yafang, L. (2014). An Empirical Study on Consumer Acceptance of Mobile Payment Based on the Perceived Risk and Trust. Proceedings of the 2014 International Conference on Cyber-Enabled Distributed Computing and Knowledge Discovery, 312317.

MobiForge. (2014). "What Is M-Commerce? How Big Is It Really? And Why Any Company Who Sells Anything Needs It, Now." Accessed on 1/02/2020 from https://internet.com/ecommerce/what-is-m-commerce-how-big-is-it-really-and-whyany-company-who-sells-anything-needs-it-now/

Nguyen, L. D. (2016). An Investigation of Critical Factors Affecting Customers' Trust in Electronic Banking: Empirical Evidence from Vietnam. (PhD Doctorate), Griffith University, Griffith University. Accessed on 28/11/2020 from https://www120.secure.griffith.edu.au/rch/items/6df25018-2f63-4a22-a146de0102b769bf/1/

Nguyen, T. A., Dick, M., \& Pham, H. C. (2020). Investigating the Critical Determinants of Trust and Their Impact on Mobile Payment Adoption. Proceedings of the 13th IADIS International Conference Information Systems 2020, Sofia University, Bulgaria, 29-36.

Patil, P., Rana, N., Dwivedi, Y., \& Abu-Hamour, H. (2018). The Role of Trust and Risk in Mobile Payments Adoption: A Meta-Analytic Review. PACIS 2018 Proceedings, 129.

Pavlou, P. A., \& Gefen, D. (2004). Building Effective Online Marketplaces with InstitutionBased Trust. Information Systems Research, 15(1), 37-59.

Peter, J. P., Sr, T., \& X, L. (1975). A Comparative Analysis of Three Consumer Decision Strategies. Journal of Consumer Research, 2(1), 29-37.

Phonthanukitithaworn, C., Sellitto, C., \& Fong, M. (2015). User Intentions to Adopt Mobile Payment Services: A Study of Early Adopters in Thailand. Journal of Internet Banking and Commerce, 20(1).

Piao, C., Wang, S., \& Yang, F. (2012). Research on Trust Evaluation Model for Mobile Commerce Based on Structural Equation Modeling. 2012 IEEE Ninth International Conference on eBusiness Engineering, 9-11 September 2012, Hangzhou, China, 25-32. 
Podsakoff, P. M., MacKenzie, S. B., Lee, J.-Y., \& Podsakoff, N. P. (2003). Common Method Biases in Behavioral Research: A Critical Review of the Literature and Recommended Remedies. Journal of Applied Psychology, 88(5), 879.

PwC. 2019. "Mobile Payments in Vietnam Fastest Growing Globally, Thailand Emerges Second in Southeast Asia." Accessed on 8/12/2020 from https://www.pwc.com/th/en/press-room/press-release/2019/press-release-30-04-19en.html

Qasim, H., \& Abu-Shanab, E. (2016). Drivers of Mobile Payment Acceptance: The Impact of Network Externalities. Information Systems Frontiers, 18(5), 1021-1034.

ResearchAndMarkets. 2020. "Covid-19 Impact on Online \& Mobile Payments Market 2020 Contactless Viewed as Cleaner Way to Pay." Accessed on 30/7/2020 from https://www.prnewswire.com/news-releases/covid-19-impact-on-online--mobilepayments-market-2020---contactless-viewed-as-cleaner-way-to-pay-301076904.html

Rouibah, K., Lowry, P. B., \& Hwang, Y. (2016). The Effects of Perceived Enjoyment and Perceived Risks on Trust Formation and Intentions to Use Online Payment Systems: New Perspectives from an Arab Country. Electronic Commerce Research and Applications, 19, 33-43. doi:https://doi.org/10.1016/j.elerap.2016.07.001

Shuhaiber, A. (2016). Factors Influencing Consumer Trust in Mobile Payments in the United Arab Emirates. (Doctor of Philosophy Doctorate), Victoria University of Wellington, Accessed on 28/11/2018 from

http://researcharchive.vuw.ac.nz/xmlui/bitstream/handle/10063/5167/thesis.pdf?sequ ence $=1$

Siau, K., \& Shen, Z. (2003). Building Customer Trust in Mobile Commerce. Communications of the ACM, 46(4), 91-94.

Siau, K., Sheng, H., \& Nah, F. (2003). Development of a Framework for Trust in Mobile Commerce. SIGHCI 2003 Proceedings, 6.

Siau, K., Sheng, H., Nah, F., \& Davis, S. (2004). A Qualitative Investigation on Consumer Trust in Mobile Commerce. International Journal of Electronic Business, 2(3), 283-300.

Slade, E., Williams, M., Dwivedi, Y., \& Piercy, N. (2015). Exploring Consumer Adoption of Proximity Mobile Payments. Journal of Strategic Marketing, 23(3), 209-223.

Slade, E. L., Dwivedi, Y. K., Piercy, N. C., \& Williams, M. D. (2015). Modeling Consumers' Adoption Intentions of Remote Mobile Payments in the United Kingdom: Extending Utaut with Innovativeness, Risk, and Trust. Psychology \& Marketing, 32(8), 860-873.

Srivastava, S. C., Chandra, S., \& Theng, Y.-L. (2010). Evaluating the Role of Trust in Consumer Adoption of Mobile Payment Systems: An Empirical Analysis. Communications of the Association for Information Systems, 27, 561-588.

Statista. 2018. "Number of Smartphone Users in Vietnam from 2015 to 2022 (in Millions)*." Accessed on 16/12/2018 from https://www.statista.com/statistics/467739/forecast-ofsmartphone-users-in-vietnam/

Straub, D. W. (1989). Validating Instruments in Mis Research. MIS Quarterly, 13(2), 147-169.

Stringfellow, A. (2018). "What Is a Mobile Payment?". Accessed on 28/11/2020 from https://www.tccrocks.com/blog/what-is-a-mobile-payment/

Venkatesh, V., Thong, J. Y., \& Xu, X. (2012). Consumer Acceptance and Use of Information Technology: Extending the Unified Theory of Acceptance and Use of Technology. MIS Quarterly, 36(1), 157-178.

Xin, H., Techatassanasoontorn, A. A., \& Tan, F. B. (2015). Antecedents of Consumer Trust in Mobile Payment Adoption. Journal of Computer Information Systems, 55(4), 1-10. 
Yan, H., \& Yang, Z. (2014). An Empirical Examination of User Adoption Mobile Paymentt. 2014 International Conference on Management of e-Commerce and e-Government, 31 October- 2 November 2014, Shanghai, China, 156-162.

Yan, Z., Niemi, V., Dong, Y., \& Yu, G. (2008). A User Behavior Based Trust Model for Mobile Applications. International Conference on Autonomic and Trusted Computing: Springer, 23-25 June 2008, Oslo, Norway, 455-469.

Zhou, T. (2011). The Effect of Initial Trust on User Adoption of Mobile Payment. Information Development, 27(4), 290-300.

Zhou, T. (2013). An Empirical Examination of Continuance Intention of Mobile Payment Services. Decision Support Systems, 54(2), 1085-1091.

Zhou, T. (2014). Understanding the Determinants of Mobile Payment Continuance Usage. Industrial Management \& Data Systems, 114(6), 936-948.

\section{Appendices}

\section{Appendix A. Survey Items}

\begin{tabular}{|c|c|}
\hline Construct and items & References \\
\hline $\begin{array}{l}\text { M-payment provider trust (PT): six items } \\
\text { PT1: Based on my perception and experience of the mobile payment provider, I know } \\
\text { they have sufficient expertise and resources to conduct mobile payment services. } \\
\text { PT2: Based on my perception and experience of the mobile payment provider, I know } \\
\text { them to be honest. } \\
\text { PT3: Based on my perception and experience of the mobile payment provider, I know } \\
\text { them to be reliable. } \\
\text { PT4: Based on my perception and experience of the mobile payment provider, I know } \\
\text { they provide secure services } \\
\text { PT5: Based on my perception and experience of the mobile payment provider, I know } \\
\text { them to be trustworthy. } \\
\text { PT6. Based on my perception and experience of the mobile payment provider, I } \\
\text { believe they have a good reputation. }\end{array}$ & $\begin{array}{l}\text { Andreev et al., 2012; } \\
\text { Srivastava et al., 2010; } \\
\text { Zhou, } 2011\end{array}$ \\
\hline $\begin{array}{l}\text { Technology trust (TT): four items } \\
\text { TT1: Based on my perception of the mobile payment technology, I know it is reliable. } \\
\text { TT2: Based on my perception of the mobile payment technology, I can know it is } \\
\text { secure. } \\
\text { TT3: Based on my perception of the mobile payment technology, I can know it is } \\
\text { trustworthy. } \\
\text { TT4. In general, I trust mobile payment technology to transact m-payment. }\end{array}$ & Srivastava et al. 2010 \\
\hline $\begin{array}{l}\text { Institution-based trust (IT): six items } \\
\text { IT1. I feel good about how things go when I use mobile payment. } \\
\text { IT2. I am comfortable making a mobile payment. } \\
\text { IT3. I believe the Internet has enough security safeguards to make me feel comfortable } \\
\text { using it to make a mobile payment. } \\
\text { IT4. I feel assured that the legal system and institutions adequately protect me from } \\
\text { mobile payment problems (such as financial frauds, and duplicate payments). } \\
\text { IT5. I feel confident that encryption and other mobile technology safeguards make it } \\
\text { safe for me to make mobile payments. } \\
\text { IT6. In general, the Internet is now a robust and safe environment in which to make a } \\
\text { mobile payment. }\end{array}$ & $\begin{array}{l}\text { McKnight et al., 2002; } \\
\text { Nguyen, 2016; } \\
\text { Srivastava et al., } 2010\end{array}$ \\
\hline $\begin{array}{l}\text { Seller trust (ST): four items } \\
\text { ST1. Based on my experience, sellers who accept mobile payment are in general } \\
\text { reliable. }\end{array}$ & $\begin{array}{l}\text { Andreev et al., 2012; Lu } \\
\text { et al., 2016; Pavlou \& } \\
\text { Gefen, } 2004\end{array}$ \\
\hline
\end{tabular}


ST2. Based on my experience, sellers who accept mobile payment are in general honest.

ST3. Based on my experience, sellers who accept mobile payment are in general trustworthy.

ST4. Based on my experience, sellers who accept mobile payment generally keep their promises.

Consumer trust (CT): four items

CT1: Mobile payment always provides accurate financial services.

CT2: Mobile payment always provides reliable financial services.

CT3: Mobile payment always provides safe financial services

CT4: Overall, I trust mobile payment

Intention to adopt m-payment (IN): three items

IN1. I intend to continue using mobile payment in the future.

IN2. I will always try to use mobile payment in my daily life.

IN3. I plan to continue to use mobile payment frequently.

Lu et al. 2011; Qasim \& Abu-Shanab 2016

Venkatesh et al. 2012

\section{Appendix B. Demographic Information}

\begin{tabular}{|c|c|c|c|}
\hline \multicolumn{2}{|l|}{ Measure } & \multirow{2}{*}{$\begin{array}{l}\text { Frequency } \\
57\end{array}$} & \multirow{2}{*}{$\begin{array}{l}\text { Percent } \\
27.9\end{array}$} \\
\hline Gender & Male & & \\
\hline & Female & 147 & 72.1 \\
\hline \multirow[t]{5}{*}{ Education } & High School & 6 & 2.9 \\
\hline & College degree / Vocational school & 5 & 2.5 \\
\hline & Bachelor degree & 116 & 56.9 \\
\hline & Master degree & 65 & 31.9 \\
\hline & PhD Degree & 12 & 5.9 \\
\hline \multirow[t]{8}{*}{ Occupation } & Employee (Office workers - white-collar worker) & 62 & 30.4 \\
\hline & Worker (Manual labourer - blue-collar worker) & 4 & 2.0 \\
\hline & $\begin{array}{l}\text { Tradesperson (electrician, plumber, carpenter, } \\
\text { mechanic) }\end{array}$ & 1 & 0.5 \\
\hline & $\begin{array}{llll}\begin{array}{l}\text { Civil servant (public servant, government } \\
\text { employee) }\end{array} & & \\
\end{array}$ & 34 & 16.7 \\
\hline & Self-employed & 10 & 4.9 \\
\hline & $\begin{array}{l}\text { Professional (scientists, accountants, doctors, } \\
\text { academic, lawyers, engineers, teachers) }\end{array}$ & 33 & 16.2 \\
\hline & Student & 46 & 22.5 \\
\hline & Others & 14 & 6.9 \\
\hline \multirow[t]{3}{*}{ Age } & $18-25$ & 74 & 35.5 \\
\hline & $26-35$ & 66 & 35.5 \\
\hline & 36 -over 55 & 64 & 29 \\
\hline \multirow{8}{*}{$\begin{array}{l}\text { Income per } \\
\text { month }\end{array}$} & To 5.000.000 VND & 56 & 27.5 \\
\hline & $5.000 .000-10.000 .000 \mathrm{VND}$ & 74 & 36.3 \\
\hline & 10.000.000 - 18.000.000 VND & 49 & 24.0 \\
\hline & $32.000 .000-52.000 .000 \mathrm{VND}$ & 18 & 8.8 \\
\hline & $52.000 .000-80.000 .000 \mathrm{VND}$ & 6 & 2.9 \\
\hline & Over $80.000 .000 \mathrm{VND}$ & 1 & 0.5 \\
\hline & Less than 3 months & 1 & 0.5 \\
\hline & From 3 to under 12 months & 1 & 0.5 \\
\hline
\end{tabular}




\begin{tabular}{|l|l|l|l|}
\hline \multirow{2}{*}{$\begin{array}{l}\text { Experience in } \\
\text { using } \\
\text { smartphones }\end{array}$} & From 1 to under 2 years & 4 & 2.0 \\
\cline { 2 - 4 } & From 2 to under 3 years & 5 & 2.5 \\
\cline { 2 - 4 } & 3 years and above & 193 & 94.6 \\
\hline \multirow{2}{*}{$\begin{array}{l}\text { Experience in } \\
\text { using m- } \\
\text { payment }\end{array}$} & Less than 3 months & 24 & 11.8 \\
\cline { 2 - 4 } & From 3 to under 12 months & 34 & 16.7 \\
\cline { 2 - 4 } & From 1 to under 2 years & 47 & 23.0 \\
\cline { 2 - 4 } & From 2 to under 3 years & 33 & 16.2 \\
\cline { 2 - 4 } & 3 years and above & 66 & 32.4 \\
\hline
\end{tabular}

Copyright: (c) 2021 authors. This is an open-access article distributed under the terms of the Creative Commons Attribution-NonCommercial 3.0 Australia License, which permits noncommercial use, distribution, and reproduction in any medium, provided the original author and AJIS are credited.

doi: https://doi.org/10.3127/ajis.v25i0.3043

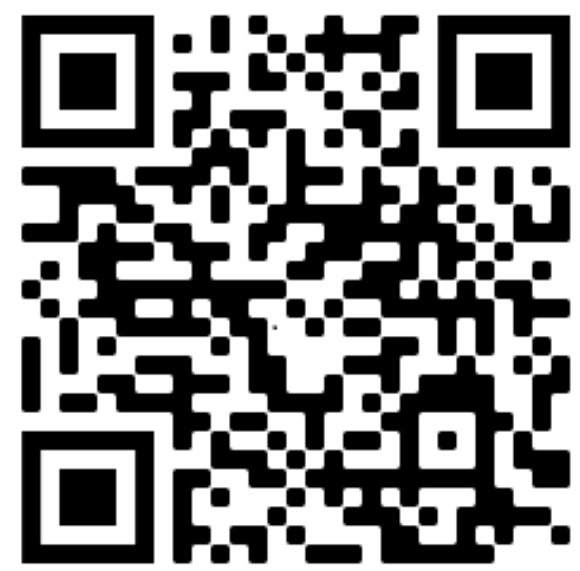

